\title{
Floristic Diversity and Indigenous Uses of Dominated Weeds in Maize Crop of Chinthapalli mandal, Visakhapatnam district, Andhra Pradesh, India.
}

\author{
${ }^{*}$ S. B .Padal, ${ }^{2}$ B. Sandhya Sri, Buchi Raju. $\mathrm{J}^{3}$ and ${ }^{4}$ B. Rama Krishna \\ 1, 2, 3, 4. Department of Botany, Mrs. A.V.N.Collage, Visakhapatnam district-530001, Andhra Pradesh, India
}

\begin{abstract}
The weed flora of maize crop in Chinthapalli mandal Visakhapatnam district was assessed to identify the weeds and evaluate their abundance. The comprehensive stock of weeds obtained was analyzed to determine the relative abundance of taxa and life forms. Forty five weed species belonging to 15 dicot families, 4 monocot families were identified. In terms of abundance and distribution, weeds of Asteraceae and Amaranthaceae were found to be far more invasive. The diversity of weed species represented by Shannon's and Simpson's and species evenness were calculated in the maize crop. Out of 45 weeds 35 weeds are Ethnomedicinal use along with local name, botanical name, family, parts used, ailments for which the drug is administered and mode of administration are presented.
\end{abstract}

Keywords: Floristic composition, weeds abundance, ethnomedicinal importance, maize crop, Chinthapalli.

\section{Introduction}

The recognition of plants as weeds is perhaps as old as agriculture itself. When land is cultivated to raise crops, weeds spring-up naturally along with the crop plants. Weeds are defined as "a plant out of place or an unwanted plant or a plant with a negative or plant that compete with man for the soil" (Kasera et al. 1998). Quite a number of plants considered as weeds in modern science have significant value in ethno-botany. Many of these naturally growing plants are not really "unwanted" in the light of traditional herbal medicine (Patnaik 1956; Govindiah 1981).

In 1956, Patnaik gave information on some useful weeds in and around Cuttack and Phatak and Oza (1958) provided information on some useful weeds of Baroda, its neighbourhood and Pavagarh of Gujarat. Weed surveys are useful for determining the occurrence and importance of weed species in crop production systems (Frick and Thomas, 1992). In1996, Bhattacharyya gave information on medico-ethno-botanical value of Saurashtra weeds. Documenting the kinds of weed species and its relative distribution facilitates the establishment of priorities for research and extension services (Mc Closky et al., 1998). The presence of weeds in the fields and their impact on the crop production and environment has been well documented (Morse et al., 1995; Randall, 1996; Froehlich et al., 2000; Hassan and Marwat, 2001).

Weeds are also played an important role in Ayurvedic medicine. Thomas and Britto (2000) reported 53 common weeds of medicinal importance which are used to cure diseases like diarrhea, dysentery, gonorrhea, rheumatism, headache, fever, worm, ulcer, urinary stone, asthma, cough etc. in Tiruneveli district of Tamilnadu. According to Saika and Hussain (2005) weeds are highly efficacious as medicine against some common diseases and other health problems of man. On the traditional uses of weeds a little work has been carried out in the India. They collected information on medicinal aspects of some weeds used by the Ahom and Khamti communities of Sivasagar. Naath et al. (2007) described ethno medicinal aspects of 38 species of weeds of Darrang district of Assam.

Chinthapalli mandal, Visakhapatnam district is one of the maize crop (Zea maize L.) growing areas it is being grown during rainy season and is a short duration crop. Hence, a large number of weeds compete for nutrients, moisture and space causing considerable yield reduction (Daulay and Singh, 1982). Weeds compete with crops for physical resources of environment, exhibit allelopathy, provide habitats for other harmful organisms cause problems during harvest, ploughing and seed purification. The farmers, therefore, control the weeds, to enhance productivity. The biology of weeds including identification and distribution, also deserve attention for effective control. The ecological information has always been pre-requisite for such efforts. Weeds of sugarcane fields (Adiseshu, 1997; Prayaga Murthy, 2009) and Weed flora of crop fields (Prayaga Murty 2009) have been taken to collect information on distribution of weeds of maize fields from different areas of Visakhapatnam district for the first time. But no work was reported on the weeds of maize crop in the district. Hence the present study was taken up on the floristic diversity and indigenous uses of dominated weeds in maize crop of Chinthapalli mandal, Visakhapatnam district to fill the back drop. 


\section{Study area}

Chinthapalli block located on the northeastern part of Visakhapatnam district, it lies between $17^{0} 44^{1}$ $22^{11}$ North latitude to $18^{0} 04^{1} 29^{11}$ North and $82^{0} 16^{1} 00^{11}$ East to $82^{0} 38^{1} 04^{11}$ East. The soils are red ferruginous loams mixed with quartzite on the hill slopes and sandy to clay in the lower slopes and villages. In valleys the soil is fertile and characterized by the presence of humus on top. Calcareous and lateritic soils are met with in the more open and badly eroded terrain. In the densely wooded parts the ground is covered with a thick layer of humus. District shows variation in climatic conditions from plain regions to hilly areas. The temperature is low and cool climate is seen in the hilly regions compared to the plains. The mean maximum temperature is $33.6^{\circ} \mathrm{C}$ and the mean minimum temperature is $21.0^{\circ} \mathrm{C}$. In some hill areas like Anantagiri, Araku, Paderu, and Chinthapalli the temperature touches to $10^{\circ} \mathrm{C}$ or even low during the months of December and January. The rainfall varies from plain to hill regions, hilly areas receive more rainfall than the plain regions. The annual rainfall in the regions is $1000-2000 \mathrm{~mm}$ while that of the plain regions is $800-1000 \mathrm{~mm}$. Out of total rainfall South-West monsoon accounts for $60-65 \%$ while North-East monsoon contributes $30-35 \%$ and the rest is shared by summer and winter showers.

\section{Material and Methods}

All the weeds encountered in the field sites (Lothugedda junction, Bennavam, Annavam, Gondipakalu, Pedabarada, Chinthapalli, Tajangi, Lambasting, Mondigadda, etc.) of the maize crop fields were carefully collected and identified. Random quadrate method was adopted for studying phytosociological attributes of weeds. Quadrates of $1 \times 1 \mathrm{~m}$ were laid down and hence a sum of 30 quadrates for maize crop. All the weeds from each quadrate were collected separately in polythene bags. All the plant species encountered in 30 quadrates were listed. Weed specimens were collected for confirmation of identify and some farmers were interviewed and questioned about problematic weeds in their farms.

The phytosociological attributes; abundance, density and frequency and their relative values and importance Value Index (IVI) were calculated the following principles of Curtis and McIntosh (1950), Misra (1968) and Mueller-Dombois and Ellenberger (1974). The species diversity calculated by Shannon' index and Simpson' index.

Frequency $(\%)=$ Total number of quadrates in which the species occur $\mathrm{X}$

100 Total number of quadrates studied

Density $=\underline{\text { Total number of individuals of a species in all quadrates }}$

Total number of quadrates studied

Abundance $=$ Total number of individuals of a species in all quadrates

Total number of quadrates in which the species occurred

Relative frequency $=$ Frequency of individuals of a species $X 100$

Total frequency of all species

Relative density $=\underline{\text { Density of individuals of a species }}$ X 100

Total density of all species

Relative abundance $=$ Abundance of individuals of a species $\quad$ X 100

Total abundance of all species

Importance Value index $=$ Relative density + Relative frequency + Relative abundance.

Plant vegetation analysis was done using Shannon' Index:

$\mathrm{H}=-\sum \mathrm{Pi} \ln \mathrm{Pi}$ where $\mathrm{Pi}=\mathrm{ni} / \mathrm{N}$ (proportional abundance of ith species)

$\mathrm{ni}=$ number of individuals of the ith species and

$\mathrm{N}=$ total number of individuals.

Simpson's index, $\mathrm{D}=1-\mathrm{C}$

Where $\mathrm{C}=\sum$ ni (ni-1) and Species Evenness, $\mathrm{E}=\underline{\mathrm{H}^{\mathrm{I}}}$
$\mathrm{N}(\mathrm{N}-1)$
$\ln \mathrm{S}$

Where $\mathrm{H}^{\mathrm{I}}=$ Shannon - Weaver Index and $\mathrm{S}=$ number of species 


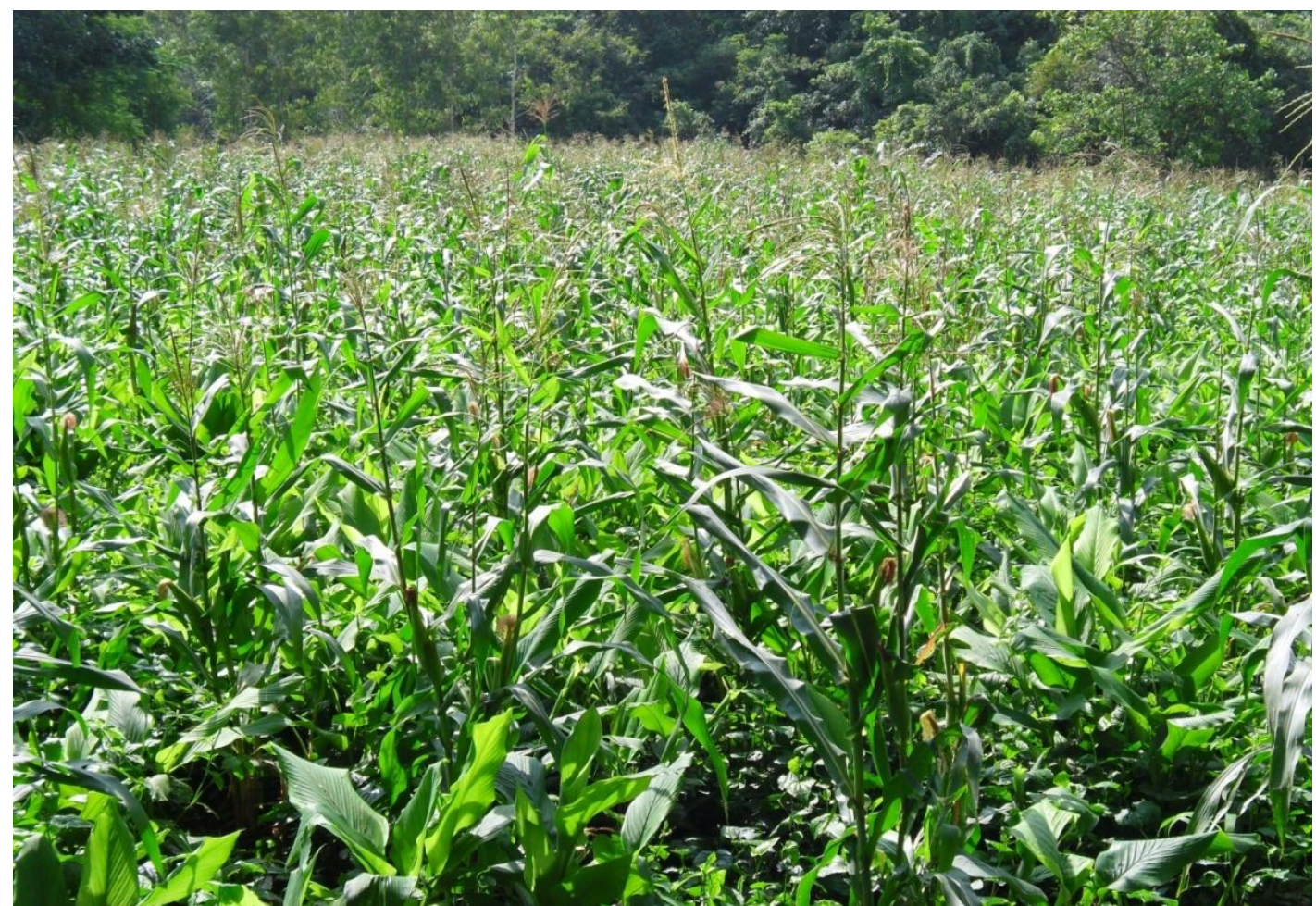

Maize crop field of Chinthapalli Mandalam.

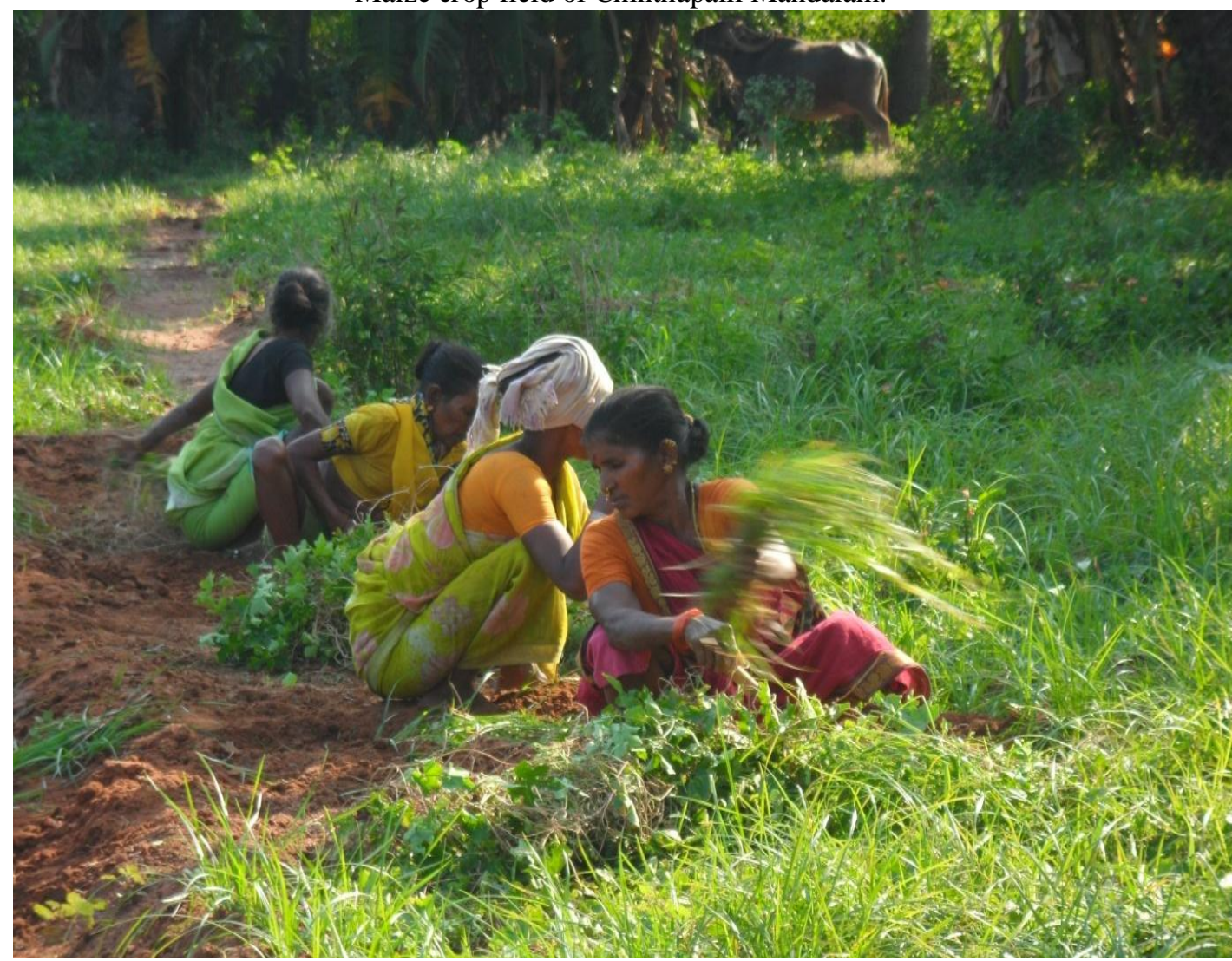

Weed eradication-Hand fulling method 
Floristic Diversity and Indigenous Uses of Dominated Weeds in Maize Crop of Chinthapalli mandal,

Table 1. Floristic diversity of weed species in Maize crop of Chinthapalli Mandalam.

\begin{tabular}{|c|c|c|c|c|c|c|c|c|c|c|c|}
\hline S.No & $\begin{array}{l}\text { Scientific name of } \\
\text { plant }\end{array}$ & Family & TOI & TNI & D & $\mathbf{F}$ & $\mathbf{A}$ & $\mathbf{R f} \%$ & Rd\% & $\mathbf{R a} \%$ & IVI \\
\hline 1 & Abutilon indicum & Malvaceae & 5 & 7 & 0.23 & 16.67 & 1.40 & 0.88 & 0.81 & 1.90 & 3.59 \\
\hline 2 & Aerva lanata & Amaranthaceae & 20 & 26 & 0.87 & 66.67 & 1.30 & 3.53 & 3.00 & 1.76 & 8.29 \\
\hline 3 & $\begin{array}{l}\text { Ageratum } \\
\text { conyzoides }\end{array}$ & Asteraceae & 25 & 34 & 1.13 & 83.33 & 1.36 & 4.41 & 3.92 & 1.84 & 10.17 \\
\hline 4 & Acalypa indica & Euphorbiaceae & 6 & 9 & 0.30 & 20.00 & 1.50 & 1.06 & 1.04 & 2.03 & 4.13 \\
\hline 5 & Achyranthes aspera & Amaranthaceae & 23 & 27 & 0.90 & 76.67 & 1.17 & 4.06 & 3.11 & 1.59 & 8.76 \\
\hline 6 & Amaranthus viridis & Amaranthaceae & 26 & 41 & 1.37 & 86.67 & 1.58 & 4.59 & 4.72 & 2.14 & 11.45 \\
\hline 7 & Bidens pilosa & Asteraceae & 30 & 40 & 1.33 & 100.00 & 1.33 & 5.29 & 4.61 & 1.81 & 11.71 \\
\hline 8 & Celosia argentea & Amaranthaceae & 6 & 8 & 0.27 & 20.00 & 1.33 & 1.06 & 0.92 & 1.81 & 3.79 \\
\hline 9 & Cissampelos pareira & Menispermaceae & 5 & 9 & 0.30 & 16.67 & 1.80 & 0.88 & 1.04 & 2.44 & 4.36 \\
\hline 10 & $\begin{array}{l}\text { Commelina } \\
\text { benghalensis }\end{array}$ & Commelinaceae & 8 & 14 & 0.47 & 26.67 & 1.75 & 1.41 & 1.61 & 2.37 & 5.40 \\
\hline 11 & Cuscuta reflexa & Cuscutaceae & 7 & 11 & 0.37 & 23.33 & 1.57 & 1.23 & 1.27 & 2.13 & 4.63 \\
\hline 12 & Cyanotis cristata & Commelinaceae & 12 & 22 & 0.73 & 40.00 & 1.83 & 2.12 & 2.53 & 2.49 & 7.14 \\
\hline 13 & Cynodon dactylon & Poaceae & 30 & 45 & 1.50 & 100.00 & 1.50 & 5.29 & 5.18 & 2.03 & 12.51 \\
\hline 14 & Cyperus difformis & Cyperaceae & 24 & 43 & 1.43 & 80.00 & 1.79 & 4.23 & 4.95 & 2.43 & 11.62 \\
\hline 15 & Cyperus rotundus & Cyperaceae & 30 & 46 & 1.53 & 100.00 & 1.53 & 5.29 & 5.30 & 2.08 & 12.67 \\
\hline 16 & Digera muricata & Amaranthaceae & 7 & 9 & 0.30 & 23.33 & 1.29 & 1.23 & 1.04 & 1.74 & 4.02 \\
\hline 17 & $\begin{array}{l}\text { Desmodium } \\
\text { triflorum }\end{array}$ & Faba & 22 & 32 & 1.07 & 73.33 & 1.45 & 3.88 & 3.69 & 1.97 & 9.54 \\
\hline 18 & $\begin{array}{l}\text { Elephantopus } \\
\text { scaber }\end{array}$ & Aste & 4 & 6 & 0.20 & 13.33 & 1.50 & 0.71 & 0.69 & 2.03 & 3.43 \\
\hline 19 & Elytraria acaulis & Acanthaceae & 30 & 43 & 1.43 & 100.00 & 1.43 & 5.29 & 4.95 & 1.94 & 12.19 \\
\hline 20 & Emilia sonchifolia & Asteraceae & 5 & 6 & 0.20 & 16.67 & 1.20 & 0.88 & 0.69 & 1.63 & 3.20 \\
\hline 21 & Eragrostis ciliata & Poaceae & 14 & 21 & 0.70 & 46.67 & 1.50 & 2.47 & 2.42 & 2.03 & 6.92 \\
\hline 22 & Euphorbia hirta & Euphorbi & 24 & 34 & 1.13 & 80.00 & 1.42 & 4.23 & 3.92 & 1.92 & 10.07 \\
\hline 23 & $\begin{array}{l}\text { Evolvulus } \\
\text { alsinoides }\end{array}$ & Convolvulaceae & 12 & 17 & 0.57 & 40.00 & 1.42 & 2.12 & 1.96 & 1.92 & 6.00 \\
\hline 24 & Justicia glauca & Acanthaceae & 4 & 6 & 0.20 & 13.33 & 1.50 & 0.71 & 0.69 & 2.03 & 3.43 \\
\hline 25 & Lasia spinosa & Araceae & 8 & 12 & 0.40 & 26.67 & 1.50 & 1.41 & 1.38 & 2.03 & 4.83 \\
\hline 26 & Lantana indica & Verbenaceae & 6 & 10 & 0.33 & 20.00 & 1.67 & 1.06 & 1.15 & 2.26 & 4.47 \\
\hline 27 & Leucas biflora & Lamiaceae & 6 & 11 & 0.37 & 20.00 & 1.83 & 1.06 & 1.27 & 2.49 & 4.81 \\
\hline 28 & Merremia gang & Convolvula & 4 & 7 & 0.23 & 13.33 & 1.75 & 0.71 & 0.81 & 2.37 & 3.89 \\
\hline 29 & $\begin{array}{l}\text { Merremia } \\
\text { hederaceae }\end{array}$ & Convolvulaceae & 7 & 10 & 0.33 & 23.33 & 1.43 & 1.23 & 1.15 & 1.94 & 4.32 \\
\hline 30 & Mimosa pudica & Mimosaceae & 13 & 24 & 0.80 & 43.33 & 1.85 & 2.29 & 2.77 & 2.50 & 7.56 \\
\hline 31 & Oxalis latifolia & Oxalidaceae & 5 & 22 & 0.73 & 16.67 & 4.40 & 0.88 & 2.53 & 5.97 & 9.38 \\
\hline 32 & Phyllanthus amarus & Euphorbiaceae & 18 & 32 & 1.07 & 60.00 & 1.78 & 3.17 & 3.69 & 2.41 & 9.27 \\
\hline 33 & Phyllanthus debilis & Euphorbiaceae & 12 & 16 & 0.53 & 40.00 & 1.33 & 2.12 & 1.84 & 1.81 & 5.77 \\
\hline 34 & Scoparia dulcis & Scrophulariaceae & 3 & 6 & 0.20 & 10.00 & 2.00 & 0.53 & 0.69 & 2.71 & 3.93 \\
\hline 35 & Setaria pumila & Poaceae & 13 & 22 & 0.73 & 43.33 & 1.69 & 2.29 & 2.53 & 2.30 & 7.12 \\
\hline 36 & Solanum nigrum & Solanaceae & 6 & 8 & 0.27 & 20.00 & 1.33 & 1.06 & 0.92 & 1.81 & 3.79 \\
\hline 37 & Sonchus oleraceus & Asteraceae & 4 & 7 & 0.23 & 13.33 & 1.75 & 0.71 & 0.81 & 2.37 & 3.89 \\
\hline 38 & $\begin{array}{l}\text { Spaeranthus } \\
\text { indicus }\end{array}$ & Asteraceae & 7 & 8 & 0.27 & 23.33 & 1.14 & 1.23 & 0.92 & 1.55 & 3.71 \\
\hline 39 & Spilanthes calva & Asteraceae & 3 & 6 & 0.20 & 10.00 & 2.00 & 0.53 & 0.69 & 2.71 & 3.93 \\
\hline 40 & $\begin{array}{l}\text { Stachytarpheta } \\
\text { jamaicensis }\end{array}$ & Verbenaceae & 7 & 12 & 0.40 & 23.33 & 1.71 & 1.23 & 1.38 & 2.33 & 4.94 \\
\hline 41 & Tridox procumbens & Asteraceae & 30 & 41 & 1.37 & 100.00 & 1.37 & 5.29 & 4.72 & 1.85 & 11.87 \\
\hline 42 & Urena lobata & Malvaceae & 4 & 8 & 0.27 & 13.33 & 2.00 & 0.71 & 0.92 & 2.71 & 4.34 \\
\hline
\end{tabular}


Floristic Diversity and Indigenous Uses of Dominated Weeds in Maize Crop of Chinthapalli mandal,

\begin{tabular}{|l|l|l|l|l|l|l|l|l|l|l|l|}
\hline 43 & Vernonia albicans & Asteraceae & 3 & 6 & 0.20 & 10.00 & 2.00 & 0.53 & 0.69 & 2.71 & 3.93 \\
\hline 44 & Vernonia cinerea & Asteraceae & 24 & 32 & 1.07 & 80.00 & 1.33 & 4.23 & 3.69 & 1.81 & 9.73 \\
\hline 45 & Vetiveria zizanoides & Poaceae & 5 & 12 & 0.40 & 16.67 & 2.40 & 0.88 & 1.38 & 3.26 & 5.52 \\
\hline
\end{tabular}

$\mathrm{D}=$ Density, $\mathrm{F}=$ Frequency, $\mathrm{A}=$ Abundance, $\mathrm{RD}=$ Relative Density, $\mathrm{RF}=$ Relative Frequency, $\mathrm{RA}=$ Relative abundance, IVI=Importance Value Index.

\section{Results}

Maize fields are severely infested with 45 weed species belonging to 41 genera and 19 families. Of these 45 species, 15 dicot families, 4 monocot families, Asteraceae and Amaranthaceae stood first and second with 10 and 5 species respectively followed by Euphorbiaceae, and Poaceae had 4 species, Convolvulaceae 3, Malvaceae, Commelinaceae, Cyperaceae, Acanthaceae, Verbenaceae each had 2 species, remaining families each one had single species.

Abundance, Density, Frequency and their relative values for determining the distribution pattern and importance Value Index (IVI) of the weeds encountered in maize crop fields was provided in Table-1. A total of 45 weed species belonging to 15 dicot families and 4 monocot families was recorded from 30 quadrates. Oxalis latifolia (Oxalidaceae) (4.40) was most abundant weed followed by Scoparia dulcis and Spilanthes calva each one has (2.00). The important value index calculated for the individual weed species encountered in field revealed interesting results. Cyprus rotundus (12.67) was the most important species followed by the Cynodon dactylon (12.51), Elytraria acaulis (12.19), Tridox procumbens (11.87) and Bidens pilosa (11.71) Table-1. The diversity of weed species represented by Shannon's (3.584) and Simpson's (0.003) and species evenness in the maize crop is (36.01). The frequency classes of the weed species encountered in the study was analyzed and frequency formula for each class also determined. It is revealed interesting results. Out of 45 Species: A class is represented by 17 species followed by 9 under B, 4 under C, 9 under D, and 6 under E class. (Table-2). Frequency formula $\mathrm{A}>\mathrm{B}>\mathrm{C}<\mathrm{D}>\mathrm{E}$. From the obtained results it is clearly established that most of the weed species encountered in the maize crop field fall under A, B, C, D and E frequency classes and hence the weed flora is relatively heterogeneous. 35 plant species and 35 genera belonging to 16 families have been recorded ethno botanical importance. Out of them 12 are dicot families and 4 are monocot families. Most of the weed species are herbs used by them to cure different ailments. Various plant parts or products viz. Stem, leaf, inflorescence, seed, root, fruit, rhizome, to be employed to make different formulations

Table 2. Ethno medicinal uses of weed species

\begin{tabular}{|l|l|l|}
\hline $\begin{array}{l}\text { S. } \\
\text { No. }\end{array}$ & Species name & Ethno medicinal uses of weeds \\
\hline 1. & $\begin{array}{l}\text { Abutilon indicum } \text { (L.)Sweet } \\
\text { Family: Malvaceae } \\
\text { Habit: Shrub } \\
\text { LN: Thuthurubenda }\end{array}$ & $\begin{array}{l}\text { The seeds are laxative and work effectively in curing piles } \\
\text { when administered in doses of 1 spoonful per day for a week } \\
\text { by the tribes. }\end{array}$ \\
\hline 2. & $\begin{array}{l}\text { Aerva lanata } \text { (L.) Juss. } \\
\text { Family:Amaranthaceae } \\
\text { Habit: Herb } \\
\text { LN: Pindikura }\end{array}$ & $\begin{array}{l}\text { Roots used for headache by the local people and also used in } \\
\text { leafy curries. }\end{array}$ \\
\hline 3. & $\begin{array}{l}\text { Ageratum conyzoides L. } \\
\text { Family: Asteraceae } \\
\text { Habit: Herb } \\
\text { LN: Pumpullu }\end{array}$ & $\begin{array}{l}\text { A hot poultice of the leaves and stem is applied on leprous } \\
\text { sores and other skin diseases. Plant juice is applied externally } \\
\text { for cuts and wounds. }\end{array}$ \\
\hline 4. & $\begin{array}{l}\text { Acalypa indica } \text { L. } \\
\text { Family: Euphorbiaceae } \\
\text { Habit: Herb } \\
\text { LN: Muripindi }\end{array}$ & $\begin{array}{l}\text { Leaves crushed with the leaves of Vitex negundo and } 3 \text { drops } \\
\text { of fresh juice administered orally and one drop each instilled } \\
\text { into eyes to cure jaundice for a period of } 3 \text { days }\end{array}$ \\
\hline 5. & $\begin{array}{l}\text { Achyranthus aspera } \text { L. } \\
\text { Family:Amaranthaceae } \\
\text { Habit: Herb } \\
\text { LN: Utthareni }\end{array}$ & $\begin{array}{l}\text { The leaf paste with that of neem and the resin of shorea } \\
\text { robusta is mixed and applied on the body for chicken pox and } \\
\text { measles. The roots are chewed for teeth infection for a period } \\
\text { of 10-15 days in the morning as a part of tooth wash }\end{array}$ \\
\hline 6. & $\begin{array}{l}\text { Amaranthes viridis L. } \\
\text { Family:Amaranthaceae } \\
\text { Habit: Herb }\end{array}$ & $\begin{array}{l}\text { Roots pound to paste with that of Oroxylum indicum and the } \\
\text { paste along with hot water is administered internally for liver } \\
\text { and spleen problems in children }\end{array}$ \\
\hline
\end{tabular}




\begin{tabular}{|c|c|c|}
\hline & LN: Thotakura & \\
\hline 7. & $\begin{array}{l}\text { Biden pilosa } \mathbf{L} \text {. } \\
\text { Family : Astareaceae } \\
\text { Habit: Herb } \\
\text { LN: Thitthirika }\end{array}$ & $\begin{array}{l}\text { Whole plant is used for cough, cold and cancer by the tribes. } \\
\text { Leaf paste is used for ear troubles, sore eyes, ulcers and } \\
\text { toothache by the tribes. }\end{array}$ \\
\hline 8. & $\begin{array}{l}\text { Celosia argentea } \mathbf{L} \text {. } \\
\text { Family:Amaranthaceae } \\
\text { Habit: Herb } \\
\text { LN: Kodi juttu }\end{array}$ & $\begin{array}{l}\text { The whole inflorescence is sun dried and pulverized into fine } \\
\text { powder. About } 10 \mathrm{gm} \text { of the powder is taken with water twice } \\
\text { daily for about two weeks to treat uterine bleeding. }\end{array}$ \\
\hline 9. & $\begin{array}{l}\text { Cissampelos pareira } \mathbf{L} \text {. } \\
\text { Family:Menispermaceae } \\
\text { Habit: Climber } \\
\text { LN: Adavi banka teega }\end{array}$ & $\begin{array}{l}\text { Leaves crushed with that of Andrographis paniculata and } \\
\text { Pongamia pinnata and the extract given orally to kill intestinal } \\
\text { worms. Three spoonfuls thrice a day for three days. }\end{array}$ \\
\hline 10. & $\begin{array}{l}\text { Commelina benghalensis L. } \\
\text { Family: Commelinaceae } \\
\text { Habit: Herb } \\
\text { LN: Enneddura kura }\end{array}$ & $\begin{array}{l}\text { Plant paste is applied on body and foot sores till they subside. } \\
\text { In cattle, plant paste is applied to treat sores. }\end{array}$ \\
\hline 11. & $\begin{array}{l}\text { Cuscuta reflexa Roxb. } \\
\text { Family: Cuscutaceae } \\
\text { Habit: Herb } \\
\text { LN: Sitamma savaralu }\end{array}$ & $\begin{array}{l}\text { Plant paste is applied for tongue ulcers. One spoonful of } \\
\text { decoction of the young plant with honey is administered once a } \\
\text { day for } 7 \text { days for epilepsy. }\end{array}$ \\
\hline 12. & $\begin{array}{l}\text { Cynodon dactylon (L.) Pers. } \\
\text { Family: Poaceae } \\
\text { Habit: Grass } \\
\text { LN: Garika }\end{array}$ & $\begin{array}{l}\text { Few leaves are pestled with } 7 \text { leaves of Zizyphus mauritiana } \\
\text { and } 7 \text { grains of raw rice and a mixture is prepared by adding } \\
150 \mathrm{ml} \text { of water to it. This taken once in a day for about } 10 \text { days } \\
\text { to treat dysuria. }\end{array}$ \\
\hline 13. & $\begin{array}{l}\text { Cyperus rotundus } \mathbf{L} \text {. } \\
\text { Family: Cyperaceae } \\
\text { Habit: Grass } \\
\text { LN: Tunga }\end{array}$ & $\begin{array}{l}\text { About } 10 \mathrm{~g} \text { of tuberous underground stolen are crushed and the } \\
\text { extract along with few drops of honey is taken for about } 3 \text { days } \\
\text { to treat diarrhea and digestion. }\end{array}$ \\
\hline 14. & $\begin{array}{l}\text { Digeria muricata (L.) Mart. } \\
\text { Family: Amaranthaceae } \\
\text { Habit: Herb } \\
\text { LN: Chencheli kura }\end{array}$ & $\begin{array}{l}\text { Leaves are used as vegetable and as laxative. Juice of whole } \\
\text { plant in doses of two spoonfuls thrice a day for two days for } \\
\text { indigestion }\end{array}$ \\
\hline 15. & $\begin{array}{l}\text { Desmodium triflorum }(\text { L.) DC } \\
\text { Family: Fabaceae } \\
\text { Habit: Shrub } \\
\text { LN: Munta mandu }\end{array}$ & $\begin{array}{l}\text { Plant extract is administered for malaria by the tribal's. } 2 \\
\text { spoonfuls twice a day for } 5 \text { days. }\end{array}$ \\
\hline 16. & $\begin{array}{l}\text { Elephantopus scaber L. } \\
\text { Family: Asteraceae } \\
\text { Habit: Herb } \\
\text { LN: Yedduadugu }\end{array}$ & $\begin{array}{l}\text { Leaf paste diluted in water and administered orally to cattle to } \\
\text { control loose motions. Leaf paste mixed with coconut oil } \\
(\text { Cocos nucifera) applied on ulcers }\end{array}$ \\
\hline 17. & $\begin{array}{l}\text { Elytraria acaulis }(\mathbf{L} . f .) \text { Lind. } \\
\text { Family: Acanthaceae } \\
\text { Habit: Herb } \\
\text { LN: Nilaven }\end{array}$ & $\begin{array}{l}\text { Leaf paste is applied on wounds and boils. Leaf juice is } \\
\text { administered in doses of two spoonfuls twice a day for } 9 \text { days } \\
\text { to treat menstrual disorders. }\end{array}$ \\
\hline 18. & $\begin{array}{l}\text { Emilia sonchifolia (L.) DC } \\
\text { Family: Asteraceae } \\
\text { Habit: Herb } \\
\text { LN: Kunka }\end{array}$ & $\begin{array}{l}\text { Leaf paste is applied on boils, bruises and wounds. Leaf paste } \\
\text { in doses of one spoonful once a day at bed time for about } 2-3 \\
\text { months to treat night blindness. }\end{array}$ \\
\hline 19. & $\begin{array}{l}\text { Euphorbia hirta } \mathbf{L} \text {. } \\
\text { Family: Euphorbiaceae } \\
\text { Habit: Herb } \\
\text { LN: Pachabottu }\end{array}$ & $\begin{array}{l}\text { Leaf extract mixed with sugar is taken } 2-3 \text { spoonfuls thrice a } \\
\text { day for dysentery. Plant juice is applied to treat wounds } \\
\text { between the toes caused by constant walking bare footed } \\
\text { during rainy season. }\end{array}$ \\
\hline 20. & $\begin{array}{l}\text { Justicia glauca } \text { Rottl. } \\
\text { Family: Acanthaceae } \\
\text { Habit: Herb } \\
\text { LN: Konda pindi }\end{array}$ & $\begin{array}{l}\text { Plant used for diabetes. Roots ground with a pinch of salt and } \\
\text { the paste is massaged for muscle pains and the extract given for } \\
\text { the same for } 2 \text { or } 3 \text { spoonfuls twice a day, till cure. }\end{array}$ \\
\hline 21. & $\begin{array}{l}\text { Lasia spinosa (L.) Thw. } \\
\text { Family: Araceae }\end{array}$ & $\begin{array}{l}\text { Rhizome paste is mildly heated and massaged over body to get } \\
\text { relief from pains. Rhizome cooked and eaten by the local }\end{array}$ \\
\hline
\end{tabular}




\begin{tabular}{|c|c|c|}
\hline & $\begin{array}{l}\text { Habit: Herb } \\
\text { LN: Salava dumpa }\end{array}$ & people. \\
\hline 22. & $\begin{array}{l}\text { Lantana camara } \mathbf{L} \text {. } \\
\text { Family: Verbanaceae } \\
\text { Habit: Shrub } \\
\text { LN: Kampu rodda }\end{array}$ & $\begin{array}{l}\text { Leaves and roots are pound to paste and the paste is applied for } \\
\text { skin diseases. The roots are used for cold and earache by the } \\
\text { tribes. The plant extract is used for nose and ear problems by } \\
\text { the local people. }\end{array}$ \\
\hline 23. & $\begin{array}{l}\text { Leucas aspera (Willd.) Link } \\
\text { Family: Lamiaceae } \\
\text { Habit: Herb } \\
\text { LN: Tella tummi }\end{array}$ & $\begin{array}{l}\text { Leaves are used for snake bite. Plant used for piles by the } \\
\text { tribal's. Whole plant is used for skin disease by the local } \\
\text { people. }\end{array}$ \\
\hline 24. & $\begin{array}{l}\text { Merremia emarginata (L.) Cuf. } \\
\text { Family: Convolvulaceae } \\
\text { Habit: Herb } \\
\text { LN: Elika Jeevaku, }\end{array}$ & $\begin{array}{l}\text { The whole plant is used for rheumatism, piles and swelling by } \\
\text { the Mali tribes. } \\
\text { Plant is used for weakness of memory, indigestion, and } \\
\text { sensation of pains by the tribes. }\end{array}$ \\
\hline 25. & $\begin{array}{l}\text { Oxalis corniculata L. } \\
\text { Family: Oxalidaceae. } \\
\text { Habit: Herb } \\
\text { LN: Pulichintaku. }\end{array}$ & $\begin{array}{l}\text { The leaves of the plants are used for fever, dysentery, scurvy } \\
\text { and cooling. Whole plant is used for diuretic, digestive } \\
\text { disorders and urinary infections by the tribes. }\end{array}$ \\
\hline 26. & $\begin{array}{l}\text { Phyllanthus amarus Schum. \& } \\
\text { Thonn } \\
\text { Family: Euphorbiaceae } \\
\text { Habit: Herb } \\
\text { LN: Nelusiri }\end{array}$ & $\begin{array}{l}\text { Whole plant is used to cure jaundice. The decoction of the } \\
\text { herb is used to cure stomachic by the tribes. The leaves pound } \\
\text { with the roots of Andrographis paniculata and the paste } \\
\text { applied on the scalp to cure infection. }\end{array}$ \\
\hline 27. & $\begin{array}{l}\text { Scoparia dulcis L. } \\
\text { Family: Scrophulariaceae. } \\
\text { Habit: Herb } \\
\text { LN: Sweet broom weed }\end{array}$ & $\begin{array}{l}\text { Plant juice is administered for fever by the tribes. Dosage of } 2 \\
\text { Spoonfuls thrice a day for } 3 \text { days. }\end{array}$ \\
\hline 28. & $\begin{array}{l}\text { Setaria italica }(\text { L.) Beauv. } \\
\text { Family: Poaceae. } \\
\text { Habit: Herb } \\
\text { LN: Korralu. }\end{array}$ & $\begin{array}{l}\text { Leaves are used for burning sensation and aphrodisiac by the } \\
\text { tribes. Caryopsis is used for pains after parturition, diuretic, } \\
\text { astringent, rheumatism and diabetes by the tribes. }\end{array}$ \\
\hline 29. & $\begin{array}{l}\text { Solanum nigrum } \mathbf{L} \text {. } \\
\text { Family: Solanaceae } \\
\text { Habit: Herb } \\
\text { LN: Kamanchi }\end{array}$ & $\begin{array}{l}\text { Plant used for dysentery plant used for stomachache in } \\
\text { children. Leaf paste is used for wounds. Fruits are used for } \\
\text { piles and fever. }\end{array}$ \\
\hline 30. & $\begin{array}{l}\text { Sphaeranthus indicus L. } \\
\text { Family: Asteraceae } \\
\text { Habit: Herb } \\
\text { LN: Bodasaramu. }\end{array}$ & $\begin{array}{l}\text { The whole plant is used for skin diseases. Seeds and roots are } \\
\text { used as anthelmintic by the local people. Leaves are used for } \\
\text { cough by the tribes. }\end{array}$ \\
\hline 31. & $\begin{array}{l}\text { Stachytarphetaurticaefolia } \\
\text { (Salisb.) Sims. } \\
\text { Family: Verbenaceae } \\
\text { Habit: Herb } \\
\text { LN: Koraputtia }\end{array}$ & $\begin{array}{l}\text { Leaves ground with that of Leucas indica and the paste applied } \\
\text { on cuts and wounds by the local people. }\end{array}$ \\
\hline 32. & $\begin{array}{l}\text { Tridax procumbens L. } \\
\text { Family: Asteraceae } \\
\text { Herb: Herb } \\
\text { LN: Gaddi chamanti. }\end{array}$ & $\begin{array}{l}\text { The leaves are reported to be employed in bronchial catarrh, } \\
\text { dysentery and diaorrhea. The leaf paste is used to control } \\
\text { bleeding of minor wounds or cuts and it cures the wounded } \\
\text { parts gradually. }\end{array}$ \\
\hline 33. & $\begin{array}{l}\text { Urena lobata Sp. } \\
\text { Family: Malvaceae } \\
\text { Habit: Herb } \\
\text { LN: Nalla benda }\end{array}$ & $\begin{array}{l}\text { The root extract is used as anthelmintic by the tribal's. Dosage: } \\
\text { spoonful twice a day for } 3 \text { days. Leaf paste is applied on head } \\
\text { for } 1 \text { hour before bath for dandruff and premature hair fall by } \\
\text { the local people. }\end{array}$ \\
\hline 34. & $\begin{array}{l}\text { Vernonia cinerea }(\text { L.) Less } \\
\text { Family: Asteraceae } \\
\text { Habit: Herb } \\
\text { LN: Sahadevi }\end{array}$ & $\begin{array}{l}\text { Fresh juice of the leaves is used against herpes, eczema and } \\
\text { ringworm. } \\
\text { Leaf extract used in malaria fever by the local people. }\end{array}$ \\
\hline 35. & Vetiveria zizanoides (L.) Nash & Oil is obtained by distillation of roots. It is used body pains. \\
\hline
\end{tabular}




\begin{tabular}{|l|l|l|}
\hline Family: Poaceae & \\
Habit: Herb & \\
LN: Vattiveru & \\
\hline
\end{tabular}

\section{Discussion and conclusion}

The frequently occurring species viz. Cyprus rotundus, Cyprus difformis, Elytraria acaulis, Cynodon dactylon, Amaranthus viridis, Tridox procumbens, Bidens pilosa, Ageratum conyzoides and Euphorbia hirta are also found in other crops where they are known to cause heavy yield losses due to competition for nutrients, water, and space. Cyprus rotundus is one of the prominent weed of the present study. It is one of the most noxious weeds of cultivation and its spread is so great and its ravages are so serious that in certain places, cultivation of fields has been actually abandoned in despair. The weed control before the flowering time the flower stalks should be chopped off with grass-cutting swords. The tubers are roasted and eaten by some people. Cynodon dactylon is one of the best and the worst grasses and its fodder is much relished by cattle and horses. But unfortunately it is the most troublesome weed in cultivated places. The eradication of the weed is extremely difficult on account of the underground stems which are very hardly and are not easy to destruct. Deep ploughing is inadvisable as the bits get buried deep in the soil. Juice is useful in the treatment of dysentery and diarrhea. Amaranthus viridis also a popular weed in maize crop. The weed is control frequently cut the flowering tops. Old plants should not be fed to cattle as the seeds pass through the alimentary canal uninjured. Leaves are eaten as a vegetable and are also used as emollient poultices. Tridax procumbens the weed is another example of an introduced in maize crop. The ease with which the plant spreads itself is greatly due to the large number of achenes produced which are capable of being dispersed over extensive areas on account of the papas of the achenes which enable them to be carried by wind. The grass-cutting sword ought to be frequently used to remove the flowering tops in waste places. 35 plant species and 35 genera belonging to 16 families have been recorded ethno botanical importance. Out of them 12 are dicot families and 4 are monocot families. Most of the weed species are herbs used by them to cure different ailments. Various plant parts or products viz. Stem, leaf, inflorescence, seed, root, fruit, rhizome, to be employed to make different formulations.

\section{Acknowledgement}

Author is grateful to agricultural officers, forest officers, local farmers and local peoples for their help during field work.

\section{Reference}

[1]. Adiseshu G. Ecological aspects of weed flora of sugarcane fields at Anakapalle Ph.D.Thesis submitted to the Andhra University,1997, Visakhapatnam.

[2]. Bhattacharyya G. Medico-Ethno-botanical value of Saurashtra weeds. J Econ Taxon Bot Additional Series, 1996. 12: 166-168.

[3]. Daulay HS, Singh KC. Chemical weed control in greengram and clusterbean. Indian J. Agric. Sci., 1982. 52 (11): 758-763.

[4]. Frick B, Thomas AG. Weed surveys in different village systems in south-western Ontario field crops. Can. J. Plant Sci., 1992, 72:1337-1347

[5]. Govindiah 1981. Role of weeds in Ayurvedic medicine. Bull Medico-Ethno-Botanical Res, 1981, 4(3-4): 144-147.

[6]. Kasara PK, Mohammed S, Chawan DD, Sen DN. Weeds of Indian desert and their chemical control. Indian journal of Environmental Sciences, 1998, 2(1): 23-27.

[7]. McClosky WB, Beker PB, Sherman W. Survey of cotton weeds and weed control practices in Arizona upland cotton fields. Publication AZ1006 cotton: College of Agric., 1998. Univ.Of Arizona.

[8]. Morse LE, Kartesz JT, Kutner LS. Native vascular plants. Our Living Resources: A Report to the Nation on the Distribution, Abundance, Health of U.S. Plants, Animals and Ecosystems. U.S. Department of the Interior, National Biological Service, Washington, DC, 1995. p. 205-209.

[9]. Nath KK, Deka P, Borthakur SK. Ethnomedicinal aspects of some weeds from Darrang district of Assam. Ethnobotany, 2007, 19(1\&2): 82-87.

[10]. Patnaik H. Some useful weeds in and around Cuttack. J Bombay Hist Soc, 1956, 54: 140-152.

[11]. ]Phatak VG, Oza GM. Some useful weeds of Baroda, its neighbourhood and Pavagarh. J Bombay Nat Hist Soc, 1958. 55: 532-542.

[12]. Randall JM. Weed control for the preservation of biological diversity. Weed Tech. 1996, 10: 370-381.

[13]. Saikia LR, Hussain I. Obnoxious weeds Sivasagar and their utility as folklore medicine among Ahom and Khamti communities. Eco Env and Cons, 2005, 11(2): 231-234.

[14]. Thomas J, Britto JD 2000. Weeds of medicinal importance in Tirunelveli district in Tamilnadu. In: JK Maheswari (Ed.): Ethnobotany and Medicinal Plants of Indian Subcontinents. Jodhpur: Vedams Books, 2000. pp. 363-367. 